\title{
JĘZYKOWY OBRAZ BIZANCJUM W POLSZCZYŹNIE DAWNEJ I WSPÓŁCZESNEJ
}

\author{
The Linguistic Picture of Byzantium in the Old and Contemporary Polish \\ Language
}

\author{
Elżbieta Skorupska-Raczyńska - Joanna Rutkowska
}

DOI: $10.17846 /$ CL.2020.13.1.144-154

\begin{abstract}
SKORUPSKA-RACZYŃSKA, Elżbieta - RUTKOWSKA, Joanna. The Linguistic Picture of Byzantium in the Old and Contemporary Polish Language. Examining the linguistic picture of the world is a major field of research in Slavic linguistics, whose aim is the analysis of experience, norms, rules and value judgements assigned to interpersonal communication - with regard to their reflection in lexis, phraseology or literature. We aim to present and assess the ways of linguistic picturing of the terms Byzantium and Byzantine over the years of their presence in the lexis; i.e. since their early conceptualisations in the Polish language and culture to the present day, thus in the diachronic and synchronic perspective. The research involves various styles of the Polish language: basic, careful (scientific, artistic, religious) and colloquial, with reference to anthropocentric perception of the reality and its linguistic interpretation. In the research process, we used the methods of excerption, analysis and synthesis, as well as an interview.
\end{abstract}

Keywords: lexis, phraseology, literature, communication, linguistic picture of the world

\begin{abstract}
Abstrakt: SKORUPSKA-RACZYŃSKA, Elżbieta - RUTKOWSKA, Joanna. Lingvistický obraz pojmu Byzancia $v$ starom a súčasnom polskom jazyku. Skúmanie lingvistického obrazu sveta je hlavná oblast výskumu v slovanskej lingvistike, ktorého ciel’om je analýza skúsenosti, noriem, pravidiel a hodnotového súdu pripisovaných interpersonálnej komunikácii - vzhladom na ich reflexiu v lexike, frazeológii alebo literatúre. Usilujeme sa prezentovat a posúdit spôsoby lingvistického zobrazenia pojmov Byzancia a byzantský v priebehu niekolkých rokov ich výskytu v lexike, t. j. od ich skorých konceptualizácií v polskom jazyku a kultúre až do dnešného dňa, teda v diachrónnej a synchrónnej perspektíve. Výskum zahŕňa rôzne štýly pol’ského jazyka: základný, „starostlivý“ (vedecký, umelecký, náboženský) a kolokviálny, ktorý odkazuje na antropocentrické chápanie reality a jej lingvistickú interpretáciu. V procese výskumu sme použili metódy excerpcie, analýzy a syntézy ako aj interview.
\end{abstract}

Klúčové slová: lexika, frazeológia, literatúra, komunikácia, lingvistický obraz sveta

Bizancjum - zapisane w dziejach cywilizacji i rozwoju komunikacyjnego ludzkości pod hasłem Cesarstwo Rzymian (Cesarstwo Wschodniorzymskie, Cesarstwo Bizantyńskie) jako fenomen rozwijający się i ewoluujący od IV wieku i funkcjonujący formalnie do połowy XV stulecia, czyli bez mała do końca średniowiecza - odegrało istotną rolę w kształtowaniu całej nowożytnej Europy. Wpłynęło na utrwalenie dziedzictwa kulturowego antycznego, na formowanie i rozkwit chrześcijaństwa, na rozwój sztuki, literatury i kultury, dało podstawyidei ustroju monarchistycznego 
i jego realizacji, pozostawiło dziedzictwo zarówno rzeczowe, jak i pozamaterialne, abstrakcyjne, czemu poświęcono tysiące opracowań - od encyklopedycznych ogólnych, poprzez monografie, po artykuły o treści skupionej na zagadnieniach szczegółowych, by przywołać dla przykładu hasło "Byzantium” w Encyklopedii The Helios (Encyklopaedia the Helios), prace zbiorową Świat Bizancjum (Świat Bizancjum 2007), dzieła Michaela Angolda (Angold 1993), Małgorzaty Dąbrowskiej (Dąbrowska 2015), Judith Herrin (Herrin 2018), Marii Jaczynowskiej (Jaczynowska 1995) czy Georgija Ostrogorskiego (Ostrogorski 2008) bądź artykuły, np. Mariana A. Wesołego (Wesoły 2019) czy Magdaleny Jaworskiej-Wołoszyn (Jaworska-Wołoszyn 2019).

Andrzej Kompa w opracowaniu popularyzującym wiedzę o Cesarstwie Bizantyńskim, jego dziejach i randze (przygotowanym pod auspicjami Komisji Bizantynologicznej Polskiego Towarzystwa Historycznego), zamieścił wykaz przykładów zasług, w którym obok wzmianki na temat znanego powszechnie artefaktu, jakim jest widelec, który „użyty w Wenecji w 1004/1005 roku przez Marię Angelopulajnę budził zdziwienie, ale odtąd ten zapomniany rzymski wynalazek ustawicznie wracał na monarsze stoły, by ostatecznie trafić [również - ESR, JR] pod strzechy (Kompa 2019, 137)", odnajdujemy informacje dotyczące wpływu Bizancjum, m.in.: na organizację i kształt europejskiej kancelarystyki oraz prawodawstwa opartego w zamyśle na prawie rzymskim; na historię i kształt ikon, czyli artystycznych wyobrażeń Jezusa i Maryi w ogólnym założeniu, a Matki Boskiej Częstochowskiej szczególnie ${ }^{1}$ - jako najstarszego typu ikonograficznego ukazującego Matkę Bożą z Dzieciątkiem, zwanego hodegetrią bizantyńską; na architekturę, również obiektów sakralnych, czego dziedzictwem są np. meczety Mimara Sinana (zwane perłami Stambułu), XVI-wiecznego architekta trzech sułtanów Turcji, inspirującego się bezsprzecznie formą architektoniczną bizantyńską; rozwój organistyki jako sztuki muzycznej - dzięki organom powszechnie znanym w Cesarstwie Rzymskim, a wysyłanym z Bizancjum na dwory monarsze zachodniej Europyjako dary, co zaowocowało zainteresowaniem instrumentem, którystałsięstałym elementem zachodniej kultury europejskiej; na losy filozofii, na której pokłady istotnie wpłynęło pośrednictwo Bizancjum, skąd rozeszła się, dzięki intelektualistom filozofom - neoplatonikom, wiedza o Platonie istotnie oddziałująca na kształt myśli i kultury renesansu; na wiedzę o literaturze antycznej Greków i Rzymian, której dzieła - z dużą dozą prawdopodobieństwa - nie zachowałyby się, gdyby nie zorganizowane prace kopistów bizantyńskich; wreszcie na kształt chrześcijaństwa. Przykłady można mnożyć, co podkreślają badacze średniowiecza, a spaja fraza „Bez Bizancjum nie byłoby Europy J. Herrin (Kompa 2019, 137)”.

Okazuje się, że wkład Bizancjum w rozwój cywilizacji i dziedzictwa kulturowego zachodniej Europy jest bezsprzecznie wielki, a udokumentowany i dowiedziony przez badaczy również polskich. Zgodnie z informacją podaną przez A. Kompę: „powszechna bibliografia bizantynistycznej literatury naukowej, prowadzona przez monachijskie «Byzantynische Zeitschrift», notuje za ostatnie 5 lat przeszło 1 tys. większych i mniejszych tekstów o Bizancjum, pisanych przez Polaków (Kompa 2019, 137)”. Zachodzi zatem pytanie o językowy obraz Bizancjum w polszczyźnie, tak współczesnej i najnowszej, jak i dawnej².

Analiza zbiorów powszechnie dostępnych słowników polszczyzny najnowszej pozwala na wyekscerpowanie z nich grupy wyrazów pokrewnych w interesującym nas polu leksykalnym

1 Por. np.: Językowy obraz Matki Bożej w XIX-i XX-wiecznych czytankach i kazaniach majowych (Rutkowska 2014); Językowa kreacja obrazu Najświętszej Panny Rokitnickiej w „Skarbie nieprzebranym dobrodziejstw Boskich” ks. Jana K. Steczewicza (Skorupska-Raczyńska, Rutkowska 2017, 155-168).

2 Pod pojęciem polszczyzny współczesnej rozumiemy leksykę języka oraz jego stan w okresie ostatnich siedemdziesięciu - osiemdziesięciu lat, a za polszczyznę najnowszą uznajemy tę funkcjonującą w ostatnich piętnastu - dwudziestu latach. Tym samym język polski wcześniejszy i starszy od polszczyzny współczesnej nazywamy na potrzeby niniejszego artykułu polszczyzna dawną. 
(15 jednostek leksykalnych), zarówno nazw własnych, jak pospolitych, których historia jest dość zróżnicowana. Wyraz Bizancjum, odnoszony do dwóch różnych desygnatów, w popularnym Uniwersalnym słowniku języka polskiego (USJP 2003, I, 273) został objaśniony jako: $1^{\circ}$ 'nazwa państwa istniejącego w okresie 395 - 1453, obejmującego niemal cały Półwysep Bałkański, Azję Mniejszą, Syrię i Egipt; cesarstwo bizantyjskie, cesarstwo bizantyńskie’; $2^{\circ}$ toponim o treści 'kolonia grecka założona w VII wieku p.n.e. nad cieśniną Bosfor, od 324 roku n.e. - pod nazwą Konstantynopol stolica oraz centrum polityczne, gospodarcze i kulturowe cesarstwa bizantyjskiego, zdobyta w XV wieku przez Turków i nazwana Stambuł (Istambuł)'; i opatrzony w wypadku obu mian kwalifikatorem hist.[oryzm] (USJP 2003, I, 273), informującym o ich przyporządkowaniu funkcjonalnym w polszczyźnie współczesnej i najnowszej. Podobnie skwalifikowane zostały towarzyszące im antroponimy (6 jednostek leksykalnych), tj.: Bizantyjczyk, Bizantyńczyk i Bizantyjka - jako nazwy mieszkańców państwa Bizancjum; oraz bizantyjczyk, bizantyńczyk i bizantyjka - odnoszone do mieszkańców miasta Bizancjum (USJP 2003, I, 273). Z wymienionych wyżej onimów w słownikach ogólnych wcześniejszych, rejestrujących polszczyznę współczesną i dawną, odnajdujemy dwa, tj. nazwę cesarstwa Bizancjum w 11-tomowym, opracowanym pod red. Witolda Doroszewskiego w połowie XX wieku, historycznym Słowniku języka polskiego (SJPD 1958-1969, I, 538) oraz wyraz bizantyńczyk w wydanym w latach 1900-1927 Słowniku warszawskim (zwanym tezaurusem polszczyzny, liczącym ok. 280000 haseł) (SW 1900-1927). Ten ostatni jednak objaśniony został tam jako 'zwolennik cywilizacji bizantyjskiej' i potwierdzony semantycznie cytatem z tekstu Włodzimierza Spasowicza (1829 - 1906), prawnika, historyka literatury i pisarza: „Jaka różnica pomiędzy małym człowiekiem z czasów królowej Anny i nami bizantyńczykami! (SW 1900-1927, I, 160)”.

W grupie pozostałych analizowanych tu wyrazów mieści się 8 nazw apelatywnych, w tym 4 terminy zaliczane do nomenklatury naukowej, czyli: bizantynistyka i bizantynologia 'dział nauk historycznych, zajmujący się badaniem dziejów i kultury cesarstwa bizantyjskiego (wschodniorzymskiego), a także bizantynista i bizantynolog 'specjalista $\mathrm{w}$ dziedzinie bizantynistyki / bizantynologii' - niepotwierdzone w wykorzystanych w niniejszym badaniu słownikach ogólnych polszczyzny współczesnej i dawnej; archaizm bizant (byzant) będący nazwą 'złotej monety bizantyjskiej'; oraz 3 jednostki leksykalne - żywe już w XIX-wiecznym obiegowym języku polskim - o różnym obecnie nacechowaniu stylistycznym, tj.: kwalifikowany jako hist. [oryczny] przymiotnik bizantyjski / bizantyński 'związany z cesarstwem Bizancjum, odnoszony do cesarstwa Bizancjum’; opatrzone skrótami książk.[owy] i przen.[ośny] określenie bizantyjski / bizantyński 'odznaczający się wschodnim przepychem i kolorytem'; oraz książk.[owy] abstrakt bizantynizm 'zespół cech charakterystycznych dla kultury, sposobu życia, obyczajów cesarstwa bizantyjskiego (wschodniorzymskiego)' (USJP 2003, I, 273). Ostatnie z wymienionych wyrazów charakteryzują się zmienną na przestrzeni ostatnich stu pięćdziesięciu lat treścią, rzutującą tym samym na barwę przekazywanego komunikatu.

Z dubletu słowotwórczego bizantyński Il bizantyjski, żywego neutralnie w polszczyźnie drugiej połowy XIX wieku na oznaczenie czegoś, co jest związane z cesarstwem Bizancjum, za starszą uznaje się formę pierwszą, czego potwierdzeniem są wyimki z ówczesnych czasopism oraz utworów literackich, co ilustrują przykłady wyekscerpowane na przykład z datowanego na 1863 rok „Tygodnika Ilustrowanego”: „Stanęła (...) prześliczna cerkiew murowana, w najczystszym stylu bizantyńskim, o pięciu kopułach (SJPD 1958-1969, I, 538)”; oraz noweli Hania Henryka Sienkiewicza, wydanej w styczniu 1876 roku: „Przed starym bizantyjskim obrazem Matki Bożej paliły się dwie świece, których blask słabo tylko rozwidniał mrok, panujący w głębi ołtarza (SJPD 1958-1969, I, 538)”. Ich neutralny charakter, nawiązujący głównie do architektury, potwierdzają kolejne cytaty, jak np. fragment $\mathrm{z}$ utworu XIX-wiecznego powieściopisarza Zygmunta Kaczkowskiego (1825-1896): „Na przedmieściach stały rozmaite kościoły i cerkwie, pomiędzy 
którymi wznosiła się na wzgórzu wspaniała i swymi bizantyńskimi kopułami imponująca cerkiew św. Jura (SJPD 1958-1969, I, 538)”, bądź z tekstu historyka literatury Michała Wiszniewskiego (1794-1865): „W pierwszych wiekach zaprowadzenia wiary chrześcijańskiej w Polsce do XII wieku, podobnie jak na Rusi i w Niemczech za Ottonów, panowała architektura bizantyńska, czyli grecka (SJPD 1958-1969, I, 538)" i innych.

Wg Andrzeja Bańkowskiego, autora wydanego (acz niekompletnie) w 2000 roku Etymologicznego słownika języka polskiego (ESJP 2000), wyraz bizantyński pochodzi od niemieckiego byzantinisch, utworzonego tam na bazie łacińskiego Byzantinus (w innym znaczeniu), co było z założenia działaniem dyskredytującym. Etymolog podkreśla bowiem, że „Historycy niemieccy nawiązali tu (w XIX) sztucznie do dawnej nazwy Nowego Rzymu: łc. Byzantium, gr. Byzántion (najpierw u Herodota), propagując przy tym pogardę dla kultury chrześcijańskiej tego państwa grecko-rzymskiego (ESJP 2000, I, 54)”. Bez względu na intencje historyków niemieckich, wyrazy bizantyński II bizantyjski po koniec XIX stulecia w Słowniku warszawskim, rejestrującym polszczyznę od jej początków do przełomu wieków XIX i XX, objaśniono semantycznie jako: 'jaskrawy, kopulasty, dziwaczny', odzwierciedlając tym żywy już wówczas i progresywny proces leksykalnej pejoratywizacji oraz generalizacji znaczeniowej. Przed upływem bowiem pierwszej połowy wieku XX w źródłach leksykograficznych rejestruje się kolejne znaczenia ww. polisemu, o treści: 'odpowiadający duchowi panującemu na dworze greckiego cesarza’ oraz 'pochlebczy, poddańczy, obłudny’ (Trzaska et al. 1939, 198). Tę ostatnią jednostkę semantyczną w polszczyźnie współczesnej rejestruje w swoich dziełach Władysław Kopaliński ('ceremonialny, dworski, poddańczy, uniżony, pochlebczy, obłudny'), zawężając ją jednak komunikacyjnie do relacji ze zwierzchnictwem, co odzwierciedla zastrzeżenie „O stosunku do władzy (Kopaliński 1989, 70; Kopaliński 1999, 69; Kopaliński 1996, 38; Kopaliński 1985, 103)”.

Przeciwny kierunek zmian dotyczy wyrazu bizantynizm ('zespół cech charakterystycznych dla kultury, sposobu życia, obyczajów cesarstwa bizantyjskiego') - obecnie zaliczanego do słownictwa starannego, o treści neutralnej i opisującej - który, zgodnie z rejestracją w Słowniku warszawskim, na przełomie wieków XIX i XX oznaczał 'hołdowanie ideom bizantyjskim’3, ale też 'sztywną etykietę dworską i pedanterię, wziąwszy pod uwagę jego objaśnienia w wówczas opracowywanych i wydawanych słownikach wyrazów obcych ${ }^{4}$ Zmianę nacechowania stylistycznego wyrazu bizantynizm dostrzec można w polszczyźnie połowy XX wieku, kiedy to, zgodnie z rejestracją leksykograficzną rozumiano go jako 'zespół właściwości ustroju, życia, obyczajów cesarstwa bizantyjskiego’, czego potwierdzenie przynosi cytowane zdanie: „Istniał ścisły związek treściowo-ideologiczny pomiędzy feudalnym systemem władzy i abstrakcyjną, formalistyczną sztuką bizantyzmu", będące bezsprzecznie znakiem czasu a wyekscerpowane z miesięcznika „Materiały do Studiów i Dyskusji z zakresu Teorii i Historii Sztuki, Krytyki Artystycznej oraz Badań nad Sztuką" z 1950 roku (SJPD 1958-1969, I, 538).

W zamieszczanych w opracowaniach i wydawnictwach leksykograficznych definicjach dostrzec można, szczególnie w wypadku opracowań autorskich, a nie kolegialnych, rys subiektywnych ocen danego zjawiska czy procesu. Przykładem może być definicja semantyczna

3 W Stowniku warszawskim dla ilustracji znaczenia wykorzystano cytat z tekstu Stanisława Krzemińskiego (1839-1912), polskiego publicysty i historyka literatury: „Bizantynizm tolerujący złe lub mianujący je dobrym" (SW 1900-1927, I, 160).

4 Por. np.: Stownik wyrazów obcych. 22000 wyrazów, wyrażeń, zwrotów i przysłów cudzoziemskich używanych w mowie potocznej i w prasie periodycznej polskiej (Arct 1907, 66); Słownik wyrazów obcych, zawierający około 14000 wyrazów obcych, zwrotów i przysłowi, używanych w języku potocznym, literackim, handlowym i korespondencji (opr. Zaturski, 1928, 56). 
wyrażenia sztuka bizantyjska w leksykonie Władysława Kopalińskiego, o treści 'pierwotnie gałąź sztuki starochrześcijańskiej, potem oficjalna sztuka kościoła ortodoksyjnego o greckim poczuciu stylu, wschodnim zamiłowaniu do przepychu, bogactwa dekoracji i kolorystyki, hieratycznie stylizowana' (Kopaliński 1999, 70), co różni ją od objaśnienia w równoległym czasowo Słowniku języka polskiego pod red. Mieczysława Szymczaka ('sztuka chrześcijańskiego wschodu, oficjalna sztuka kościoła ortodoksyjnego z głównym centrum w Bizancjum, której tradycje przetrwały w sztuce ruskiej i bałkańskiej do XIX wieku; charakteryzowało ją zamiłowanie do przepychu i bogactwa dekoracji, wyczucie koloru, monumentalność, hieratyczność, a jednocześnie zbliżenie do natury; w architekturze - charakterystyczne bazyliki') (Szymczak 1993, I, 171), zdecydowanie o większym poziomie obiektywizmu.

Z cytowanych wyżej kilkunastu wyrazów pokrewnych zebranych w interesującym nas gnieździe leksykalnym w powszechnym i popularnym obiegu dostrzegamy obecnie dwa, tj. Bizancjum / bizancjum $^{5}$ i bizantyjski (bizantyński), przywoływane standardowo dla ilustracji niewłaściwego postępowania, rażącej zachłanności, wręcz rozpasania w życiu publicznym, prowadzących niechybnie do upadku państwa, a zarzucanych głównie przeciwnikom politycznym i służące ich dyskredytacji. Oto przykłady zebrane przez A. Kompę, odzwierciedlające semantyczny zakres wykorzystanych w wypowiedziach przez osoby znane publicznie wyrazów Bizancjum oraz bizantyjski:

- „Jak sądy rejonowe mogą funkcjonować sprawnie, skoro połowa sędziów to funkcyjni? Chcę ukrócić to Bizancjum” (Jarosław Gowin, 2012 rok; jako minister sprawiedliwości);

- „Pan musi zacząć oszczędzać od siebie, pan musi zlikwidować swoje Bizancjum. Musi pan zlikwidować gabinety polityczne i inne nikomu niepotrzebne, a kosztowne rozwiązania” (Beata Kempa, 2011 rok; w Sejmie RP, do Donalda Tuska po wygłoszonym przez niego expose);

- „Zastałam tu straszne Bizancjum. Po co mi 16 samochodów? Mam największy gabinet ze wszystkich ministrów, tu jest kilka pokoi, w tym coś na kształt sali kinowej, wielka łazienka" (Anna Zalewska, 2015 rok; po objęciu stanowiska ministra edukacji);

- „Chodzi o uspołecznienie i oddanie kultury w ręce ludzi, którzy mają pasję, znają się na tym i przyjmują za to odpowiedzialność. I o zmianę sposobu funkcjonowania instytucji, żeby nie był bizantyjski, ale nowoczesny” (Agnieszka Holland; 2009 rok; z wywiadu dla „Gazety Wyborczej");

- „Raz na zawsze uczynił on zbędnymi bizantyjskie rokowania o utworzenie rządu z trzymanym za plecami sztyletem” (Arkadiusz Stempin, 2013 rok; o politykach włoskich) (Kompa 2019, 135).

Z cytowanych przykładów wypowiedzi wynika, iż Bizancjum / bizancjum i bizantyjski stereotypowo $\mathrm{w}$ obiegowej polszczyźnie najnowszej identyfikują przesyt, przerost, zbytek i przesadę, nieuzasadnioną wystawność i obfitość, niegospodarność i rozrzutność oraz marnotrawstwo, a także zacofanie, fałsz i jednowładztwo. Taki obraz, styl oceny i sposób kategoryzowania otaczającego świata chętnie podejmowany jest przez dziennikarzy w powszechnie dostępnych środkach masowego przekazu, m.in. w prasie codziennej i w tabloidach, co ilustrują - przykłady tytułów: „PiS kończy z «bizancjum», ale BOR potrzebuje limuzyn. Luksusowych” (www.gazetalubuska.pl 2016); „Tropienie «Bizancjum» $\mathrm{i}$ «centrum libacji»? Rząd PiS walczy z konkurencją w iście tabloidowym stylu” (www.mobile.natemt.pl 2016); „1,6 mln zł nagród w Trybunale Konstytucyjnym. Bizantyjskie premie od prezes Julii Przyłębskiej” (www.wiadomości.wp.pl 2018); „„Bizancjum PiS» czy «pokora, umiar» - sprawdzamy, czy wzrosły wydatki instytucji państwowych” (www.konkret24.tvn24.pl 2019) ${ }^{6}$; tendencyjnie skonstatowane newsy, jak dotyczący wizyty Beaty Kempy w Jordanii „To chyba

5 Jako wyraz pospolity zarejestrowano to hasło w Wielkim słowniku wyrazów bliskoznacznych PWN (Bańko 2005, 55).

6 Dostęp do ww. źródeł: 18.09.2019. 
nie tak miało wyglądać. Nowa minister ds. uchodźców Beata Kempa poleciała do Jordanii, żeby na miejscu sprawdzić, jak żyje się w obozach dla uchodźców. Jej podróż wywołała jednak kpiny. (...) A wszystko przez bizantyjską oprawę wyjazdu”, poprzedzony znamiennym zwiastunem: „Kempa poleciała do Jordanii spotkać się z uchodźcami. Zabrała cały orszak, pławiła się w luksusach”; komentarze, by przywołać wyimek z felietonu Rafała A. Ziemkiewicza: „AAfera» polegająca na tym, że latał [Marszałek Sejmu RP - ESR, JR], byłaby w ogóle śmieszna i płynąca z idiotycznego kultu państwa z dykty, które każe z ogłupiałym z nienawiści do władzy mediom ogłaszać jakimś Bizancjum rzeczy oczywiste - to, że politycy korzystają z ochrony, że Lech Kaczyński jako prezydent Warszawy przyjmował zagranicznych gości w eleganckiej restauracji, zamiast w barze mlecznym etc. (Ziemkiewicz 2019, 7)”; a także parafrazowany przekaz wystąpień polityków, jak w wypadku streszczenia wypowiedzi Kazimierza Marcinkiewicza z kwietnia 2018 roku: „Były premier nazwał sposób sprawowania władzy przez PiS «bizantyjski», na czele którego stoi jego «cesarz», Jarosław Kaczyński”". Jako wypowiedzi dziennikarskie upowszechniają one de facto pojęcia bizancjum i bizantyjski w zmienionym współcześnie i spejoratywizowanym znaczeniu. Bardziej jednak niepokojące są opinie o Bizancjum jako dziedzictwie kulturowym ludzkości wygłaszane arbitralnie przez tzw. celebrytów, by przywołać fragment z wypowiedzi Roberta Biedronia w sierpniu 2019 roku: „Kiedyś symbolem rozpasania - znamy to z historii - było Bizancjum. Przez ostatnie 4 lata PiS w Polsce zbudowało PiS-ancjum - system, w którym rozpasanie władzy, polityków, rządzących sięgnęło zenitu" ", potęgujący niechęć do obozu rządzących, ale i tym samym idiosynkrazję w odniesieniu do dziedzictwa średniowiecznego imperium bizantyjskiego. Wprawdzie, jak podkreśla M. A. Wesoły, „pogardliwe nastawienie do Bizancjum nie jest czymś nowym, ale pochodną tego, jak już w zachodnim średniowieczu postrzegano Cesarstwo Konstantynopola (Wesoły 2019, 22)", ale posługiwanie się dyskredytującymi podmiot epitetami Bizancjum / bizancjum i bizantyjski wymaga - jak w wypadku każdej jednostki komunikacyjnej - elementarnej wiedzy podstawowej, przynajmniej w wymiarze absolutnego minimum.

Postrzeganie Bizancjum w popularnym obiegu jest zróżnicowane, co odzwierciedlają wypowiedzi respondentów w ankiecie przeprowadzonej wśród 142 studentów pierwszego roku Akademii im. Jakuba z Paradyża w Gorzowie Wielkopolskim ${ }^{10}$, różnych kierunków studiów, tj.: z zakresu nauk ekonomicznych (finanse i rachunkowość: 22); humanistycznych (filologia: 26, komunikacja medialna i społeczna: 9); inżynierskich (informatyka: 18); o kulturze fizycznej (turystyka i rekreacja: 7); o zarządzaniu i bezpieczeństwie (bezpieczeństwo narodowe: 12, logistyka: 16, zarządzanie: 11); prawnych (kryminologia stosowana: 11) oraz społecznych (pedagogika: 10). Okazuje się bowiem, że podstawowa identyfikacja nazwy Bizancjum w zasadzie nie stanowi problemu, skoro znacząca większość ankietowanych - 88,7\% dokonała poprawnego wyboru, wskazując na „cesarstwo” (110 osób; 77,4\%) lub „miasto” (16 osób; 11,3\%), a mniejszość - 11,3\%

\footnotetext{
www.mobile.natemat.pl 2019.

www.wiadomości.wp.pl 2019.

Za: www.gazetaprawna.pl 2019.

10 Studenci odpowiedzieli na 7 następujących pytań otwartych:

1. BIZANCJUM to... (podkreśl właściwą odpowiedź) archetyp, cesarstwo, miasto, tkanina, obiekt architektury, wyznanie religijne, inne (wskaż).

2. Wskaż 5 aspektów związanych z BIZANCJUM (wybierz z wymienionych: apostolat, buddyzm, demokracja, filozofia, konserwatyzm, konstytucja, kultura, literatura, łacina, patriarchat, inne (jakie?).

3. Co to jest bizantynistyka? Wyjaśnij.

4. Czym zajmuje się bizantynologia? Wyjaśnij.

5. Wyjaśnij określenie bizantyjski.

6. Wyjaśnij określenie bizantyński.

7. Wskaż epokę w dziejach ludzkości, z którą można powiązać BIZANCJUM.
} 
(16 osób) wybrało odpowiedź błędną. Jednak już językowa konceptualizacja Bizancjum, jaką wywołuje pytanie drugie ankiety ${ }^{11}$, odbiega od powyższego wyniku, ponieważ z zaproponowanego zestawu dziesięciu haseł połowa z ankietowanych wybrała cztery, tj.: „filozofia” (54,2\%), „literatura” (50,7\%), „kultura” (48,6\%) i „łacina” (47,2\%). Ponad 1/3 (37,3\%) respondentów wskazała ingredient „patriarchat”, ale bez mała 1/5 (19,7\%) badanych kojarzy Bizancjum z „demokracją”.

Równie trudne okazały się kolejne zadania (trzecie i czwarte), w których poproszono respondentów o odpowiedź na pytania: Co to jest bizantynistyka? oraz Czym zajmuje się bizantynologia?, ponieważ w obu wypadkach ponad 3/5 badanych (62,7\% i 63,4\%) nie udzieliło odpowiedzi. Odpowiadając na pierwsze z cytowanych wyżej, 35,2\% sformułowało trafną definicję, a $2,1 \%$ błędną. W odniesieniu do drugiego odnajdujemy 30,3\% objaśnień poprawnych, a 6,3\% błędnych, m.in. o treści: „Nauczaniem”; „Interpretacją filozofii bizantyjskiej”; „Inna bliskoznaczna nazwa bizantyjski”; „Rozkład na czynniki pierwsze nauki o Bizancjum”; „Zajmuje się nauką języka, jaki był w Bizancjum" itp. Podobnie niełatwe dla ankietowanych okazały się zadania (piąte i szóste) polegające na zdefiniowaniu pojęć bizantyjski i bizantyński, z których pierwsze poprawnie objaśniło niewiele ponad 1/4 ankietowanych (38 osób; 26,8\%), spośród których zdecydowana większość - 36 osób; 25,4\% - odniosła się do prototypowego znaczenia wyrazu („Pochodzący z Bizancjum”; „Charakterystyczny dla Bizancjum”; „Związany z kulturą Bizancjum” itp.), a jednostkowo - 2 osoby; 1,4\% - wskazano znaczenie wtórne („Rozrzutny, bogaty, dostatni, pełen obfitości styl życia” itp.). Odpowiedzi błędnej z kolei udzielił co dwudziesty ankietowany (7 osób; 4,9\%). Dodać tu należy, iż tego z pozoru prostego zadania nie podjęło ponad $2 / 3$ badanych, o czym świadczy nieudzielenie odpowiedzi przez 97 osób (68,3\%). Konsternację natomiast wywołał jego wariant synonimiczny, czyli forma bizantyński funkcjonująca obiegowo w uznanym przez normę dublecie leksykalnym bizantyjski \| bizantyński (wskazany do objaśnienia w zadaniu 6.), który należało lub można było zinterpretować jako 'inaczej bizantyjski', odwołując się tym samym do treści zadania poprzedniego. W efekcie odsetek osób, które zignorowały polecenie, wzrósł o bez mała 20 pkt procentowych (123 osoby; 86,6\%), zaś wyzwanie podjęło łącznie 19 studentów, formułując odpowiedź poprawną (14 osób; 9,9\%) bądź błędną (5 osób; 3,5\%). O próbach poszukiwania właściwej odpowiedzi może świadczyć przykład: „Wydaje mi się, że jest to synonim bizantyjskiego" - zapisany w jednej z ankiet.

Próbę historycznej lokalizacji Cesarstwa Bizantyńskiego (zgodnie z poleceniem zamykającym ankietę: Wskaż epokę w dziejach ludzkości, z którą można powiązać Bizancjum) podjęła większość respondentów, tj. 85 osób (59,8\%), rzadziej jednak udzielając poprawnej odpowiedzi - 31 osób $(21,8 \%)$, a częściej błędnej - 54 osoby (38\%). Tę ostatnią grupę dopełniają ankietowani - 57 osób (40,2\%), którzy zrezygnowali z realizacji zadania.

Resumując. Wyniki przeprowadzonej próby badawczej wśród studentów pierwszego roku studiów, czyli młodych ludzi z pełnym wykształceniem średnim, ze względu na jej niewielki zasięg nie upoważniają do ferowania opinii, a tym bardziej wyroków, skłaniają jednak do refleksji nie tylko nad stanem wiedzy historycznej czy kompetencji językowej, ale i sprawności komunikacyjnej społeczeństwa. Okazuje się, że ankietowani mają w zasadzie wiedzę na temat Bizancjum, ale bierną, tym samym i połowiczną, skoro w wypadku zadań z podpowiedzią, większość odtwórczo korzystając z możliwości wyboru - wskazuje poprawne odpowiedzi; w sytuacji samodzielnej, czyli de facto twórczej czynności, nie radzą sobie ze sformułowaniem poprawnego pojęcia bądź jego objaśnieniem.

Tytułem podsumowania. Grupa słownictwa pokrewnego w gnieździe onimu Bizancjum jest w polszczyźnie stosunkowo młoda, skoro początki funkcjonowania określonych w nim jednostek leksykalnych odnajdujemy - zgodnie z rejestracją w źródłach leksykograficznych - w języku polskim

11 Patrz przypis poprzedni (10). 
drugiej połowy XIX wieku. Ich uzasadnienie funkcjonalne wiąże się w tym okresie z rozwojem wiedzy i zamiłowaniem do orientu i antyku, zapoczątkowanym w czasach romantyzmu i rozkwitającym w kolejnych dziesięcioleciach doby nowopolskiej, czego odbicie odnajdujemy m.in. w dziełach literackich np. epoki pozytywizmu bądź listach z podróży. W wieku XX i początkach XXI stulecia analizowane słownictwo po części uległo zmianom stylistycznym, czego odzwierciedleniem jest ich naukowa kwalifikacja terminologiczna, oraz w kilku wypadkach semantycznym, w wyniku procesu przekształceń znaczeniowych częściowych i postępującej pejoratywizacji, co świadczy o pierwszych już wówczas zmianach w językowym obrazie Bizancjum.

Konceptualizacja rzeczywistości de facto odbywa się, odwołując się do teorii kognitywizmu i językoznawstwa kognitywnego, czyli funkcjonalistycznego (Tabakowska 2001), zgodnie ze schematem opartym na dwóch członach; są to poznanie i porównanie. U jej podstaw leży antropocentryczne postrzeganie świata, które przebiega na osi: postrzegam $\rightarrow$ pojmuję $\rightarrow$ nazywam. Postrzegam - z racji uczestnictwa w tym, co dzieje się wokół; pojmuję - przez pryzmat własnych doświadczeń i przeżyć (pozytywnych, negatywnych i emocjonalnie neutralnych), ale też percepowanych informacji o różnym stopniu subiektywności lub obiektywności narzuconym przez ich nadawcę; nazywam - zgodnie z posiadanymi, nabytymi, ukształtowanymi i wykształconymi umiejętnościami. Te zaś z punktu widzenia wiedzy o języku i komunikacji mogą być różne. Mówi się również, że owo postrzeganie jest zdroworozsądkowe, ale i naiwne, jako powiązane z posiadaną wiedzą bądź z jej brakiem.

W wypadku intensywnego (a może nawet agresywnego) przekazu informacji (jawnie i kontekstowo), odwołującego się do wybranych przez nadawcę komunikatu uczuć określonego $\mathrm{w}$ akcie komunikacji odbiorcy, tworzy się obraz - jednoznaczny, opcjonalny, ambiwalentny, ale też standardowy, o takich, a nie innych ramach zakreślonych przez autora wypowiedzi, świadomie wykorzystującego przekaz językowy do uaktywnienia odpowiedniej kliszy konceptualizacyjnej, zwanej też stereotypem.

Stereotyp, czyli uproszczony i często niesprawiedliwie oraz krzywdząco wartościujący rzeczywistość szablon odnoszony do osób, grup społecznych, organizacji i instytucji, rzeczy, procesów i zjawisk (USJP 2003, III, 1391), w języku rodzi się szybko, a umiera powoli. Jego trwałość zależy od wielu wprawdzie aspektów, ale u jej podstaw leży z dużą dozą prawdopodobieństwa szczególnie w czasach powszechnej dostępności do popularnych środków masowego przekazu o szerokim i szybkim oddziaływaniu na opinię publiczną - podatność gruntu, na którym wzrasta. Dlatego też stereotyp Bizancjum / bizancjum (bizantyjski), konceptualizujący w wypowiedziach nadmiar, rażący przepych, krzywdzący innych i ich kosztem konsumowany przez wybrańców luksus, a także fałsz, podstęp i tyranię, kształtował się w polszczyźnie w poprzednich latach bardzo wolno, zważywszy na jego sygnały w literaturze pięknej początków XX wieku (Berent $1975,30)^{12}$, w przeciwieństwie do np. niezwykle popularnego, bardzo młodego, ale przejrzystego komunikacyjnie stereotypu wywoływanego hasłem moherowe berety (mohery) na określenie osób, zazwyczaj starszych, identyfikowanych z konserwatywnym nurtem polskiego katolicyzmu.

W wypadku Bizancjum o omawianej tu semantyce, z punktu widzenia językoznawstwa (także kognitywistycznego) mamy do czynienia z pojęciem odnoszonym do informacji, jakimi posługuje

12 Przykładem stereotypizacji i negatywnego nacechowania mogą być fragmenty z powieści Ozimina Wacława Berenta, wydanej w 1911 roku: „Każde Bizancjum (...) w starszym pokoleniu mumifikowało się tylko, rozkładało zaś właśnie w młodym, właśnie w tym, które mu użyczało pozornego ruchu na powierzchni”; „Święci się leniwego fatum panichida bizantyjska - ponure rozgrzeszenie odpowiedzialności niczyjej. Za wielką jest ta ojczyzna ziemi połowy, żaden wicher jej z końca w koniec nie przebieży; jakżeby wola ludzka ogarnąć ją mogła? (...) wszystko się wzajem zbydlęca w swym człowieczeństwie bolesnym i leczy drętwieniem wspólnym" (Hertz - Kopaliński 1975, 30). 
się grupa użytkowników języka o wysokim poziomie wiedzy uznawanej obiegowo za humanistyczną (historycznej, filozoficznej, literackiej czy z zakresu sztuki). Tym samym wyrazy Bizancjum i bizantyjski, ze względu na niewysoki stopień upowszechnienia wiedzy na temat ich pierwotnego przyporządkowania funkcjonalnego, nie dają możliwości realizacji procesu konceptualizacji świata i jego elementów, jakim jest porównanie, co oznacza, że potocznie wyrazy te w swym zmienionym znaczeniu będą identyfikowane $\mathrm{z}$ tym, co jest znane i pozwala na czytelną konkretyzację desygnatu o treści: rozpasanie, rozrzutność, przepych itd. $Z$ dużą dozą prawdopodobieństwa będzie to obiekt irytujący przeciętnego użytkownika języka i wywołujący gniew i złość osób komunikacyjnie usytuowanych poniżej przeciętnej wiedzy, dla których Bizancjum i bizantyjski oznaczać będą jedynie (albo w przewadze) fakty nieakceptowane społecznie ze względu na ich socjalną i materialną (w porównaniu $\mathrm{z}$ otaczającą rzeczywistością) wybujałość.

Przyjąć jednak należy, że w powszechnym obiegu wyrazy Bizancjum i bizantyjski odnoszone są $\mathrm{z}$ dużą dozą prawdopodobieństwa przede wszystkim do ich prototypowych znaczeń przyporządkowanych historii, filozofii, kulturze i sztuce, co sugerują wyniki próby badawczej przeprowadzonej wśród studentów pierwszego roku studiów różnych kierunków na uczelni usytuowanej w mieście o średniej wielkości na pograniczu zachodnim Polski. Nieznaczący odsetek respondentów w objaśnieniach zawartych $\mathrm{w}$ ankiecie wskazuje wtórne znaczenie wyrazów Bizancjum i bizantyjski, tak chętnie podejmowane w tzw. dyskusjach politycznych i wykorzystywane do stygmatyzowania przeciwników.

Na podstawie obecnej popularności (niewielkiej czy znaczącej?) nacechowanych pejoratywnie jednostek leksykalnych Bizancjum / bizancjum i bizantyjski trudno jednoznacznie określić kierunek ich ewolucji i wskazać progresywność bądź recesywność komunikacyjną. Pewne jest, iż zakres wiedzy umacniającej i waloryzującej prototypowe znaczenia analizowanych na wstępie terminów historycznych lub wtórne, po zmianie semantycznej częściowej, obecnie książkowe, ale $\mathrm{w}$ żywym komunikacie $\mathrm{z}$ dużym ładunkiem ekspresywności i używane $\mathrm{w}$ kontekście o dyskredytującym nacechowaniu opisu bądź oceny, zależy również od świadomości odbiorcy komunikatu. Ta zaś może: dyskwalifikować ich wtórne znaczenie dzięki wysokiej wiedzy o przeszłości albo je akceptować ad hoc mimo jej niepełności bądź odrzucić z powodu braku ingredientu historycznego, umożliwiającego skuteczną realizację porównania.

Współczesne i najnowsze źródła leksykograficzne rejestrują leksykę w polu słowotwórczym związanym z Bizancjum przede wszystkim jako historyzmy i antroponimy książkowe (np. Bizantyńczyk i bizantyńczyk), a także słownictwo przenośne (np. bizantyjski 'odznaczający się wschodnim przepychem i kolorytem'), co wskazuje na jej przyporządkowanie funkcjonalne w zasadzie do odmiany pisanej polszczyzny. W językowym obiegu komunikacyjnym, w zasadzie w polszczyźnie mówionej wykorzystywane są one (głównie Bizancjum / bizancjum i bizantyjski) jako formy o negatywnym ładunku treści.

Językowy obraz Bizancjum ma we współczesnej i najnowszej polszczyźnie dwie odsłony $\mathrm{z}$ jednej strony i de facto prywatnie opiera się on na wiedzy historycznej, przekazanej w procesie edukacji głównie szkolnej, poszerzonej ewentualnie indywidualnie, o czym świadczą wyniki próby badawczej. Z drugiej strony jest to odsłona nakładana publicznie jako dyskredytująca maska, nacechowana pejoratywnie $\mathrm{w}$ wypowiedziach publicznych. Ta pierwsza wykazuje $\mathrm{z}$ dużą dozą prawdopodobieństwa szerszy zasięg (co potwierdzają swymi wypowiedziami sami ankietowani), ale o charakterze zanikowym, ze względu na ograniczony czasowo (na poziomie edukacji szkolnej) przekaz wiedzy na temat Cesarstwa. Ta druga ma zdecydowanie większą siłę ekspansji, co umożliwiają środki masowego przekazu oraz popularyzacja negacji, alienacji, kontestacji i krytykanctwa w kontaktach publicznych.

Bez względu na hipotetyczny kierunek rozwoju jednostek leksykalnych pokrewnych Bizancjum (ich progresję czy regresję), wpływających w polszczyźnie najnowszej istotnie na jego aktualnie 
propagowany językowy jego obraz, koniecznym jest szerzenie - począwszy od edukacji na poziomie podstawowym - a następnie popularyzowanie wiedzy na temat Cesarstwa Bizantyńskiego, jego istoty i kultury, a tym samym ważkiego wpływu na rozwój dziedzictwa europejskiego.

\section{REFERENCES}

Angold, Michael. 1993. Cesarstwo Bizantyjskie 1025 : 1204: historia polityczna, przekł. W. Brodzki. Wrocław (Zakład Narodowy im. Ossolińskich).

Arct, Michał. 1907. Słownik wyrazów obcych. 22000 wyrazów, wyrażeń, zwrotów i przysłów cudzoziemskich używanych w mowie potocznej i w prasie periodycznej polskiej. Warszawa.

Bańko, Mirosław (ed.). 2005. Wielki słownik wyrazów bliskoznacznych PWN, Warszawa.

ESJP. 2000. Bańkowski, Andrzej. Etymologiczny słownik języka polskiego, t. I-II (do pyza).

Warszawa.

Dąbrowska, Małgorzata. 2015. Drugie oko Europy, Bizancjum w średniowieczu. Wrocław.

SJPD. 1958-1969. Doroszewski, Witold (ed.). Słownik języka polskiego. T. I-XI. Warszawa.

USJP. 2003. Dubisz, Stanisław (ed.). Uniwersalny słownik języka polskiego. T. I-IV. Warszawa.

Dzieje Bizancjum. Zaginione cesarstwo, „Pomocnik Historyczny”. 2019. Nr 1. Warszawa.

Encyklopaedia the Helios, 1952. Helios New Encyclopedic Dictionary.

Herrin, Judith. 2018. Niezwykłe dziedzictwo średniowiecznego imperium, przekł. N. Radomski. Poznań.

Hertz, Paweł - Kopaliński, Władysław. 1975. Księga cytatów z polskiej literatury pięknej od XIV do XX wieku. Warszawa.

Jaczynowska, Maria. 1995. Dzieje Imperium Romanum. Warszawa.

Jaworska-Wołoszyn, Magdalena. 2019. Filozofia w Bizancjum - biała plama w świadomości europejskiej. In Stempin, Agnieszka (ed.). Geniusz Europy. Poznań, 31-43.

SW 1900-1927. Karłowicz, Jan et al. Słownik języka polskiego. T. I-VIII. Warszawa.

Kompa, Andrzej. 2019. Nie tylko widelec. Co Europa zawdzięcza Bizancjum?. In Dzieje Bizancjum. Zaginione cesarstwo, „Pomocnik Historyczny”. 2019. Nr 1. Warszawa, 137.

Kompa, Andrzej. 2019. Widziane z Polski, Dzieje Bizancjum. In Dzieje Bizancjum. Zaginione cesarstwo, „Pomocnik Historyczny”. 2019. Nr 1. Warszawa, 134-136.

Kopaliński, Władysław. 1985. Słownik mitów i tradycji kultury. Warszawa.

Kopalinsski, Władysław. 1989. Słownik wyrazów obcych i zwrotów obcojęzycznych. Warszawa.

Kopaliński, Władysław. 1996. Słownik eponimów czyli wyrazów odimiennych. Warszawa.

Kopaliński, Władysław. 1999. Słownik wyrazów obcych i zwrotów obcojęzycznych z almanachem. Warszawa.

Morrison, Ceccile (ed.). 2007. Świat Bizancjum. T. I: Cesarstwo Wschodniorzymskie, przekł. A. Graboń, Kraków.

Ostrogorski, Georgij. 2008. Dzieje Bizancjum. Warszawa.

Rutkowska, Joanna. 2014. Językowy obraz Matki Bożej w XIX- i XX-wiecznych czytankach i kazaniach majowych, Gorzów Wielkopolski.

Skorupska-Raczyńska, Elżbieta - Rutkowska, Joanna. 2017. Językowa kreacja obrazu Najświętszej Panny Rokitnickiej w „Skarbie nieprzebranym dobrodziejstw Boskich” ks. Jana K. Steczewicza.

In Język. Religia. Tożsamość. Nr 2 (16). Gorzów Wielkopolski, 155-168.

Szymczak, Mieczysław (ed.). 1993. Słownik języka polskiego. T. I-III. Warszawa.

Tabakowska, Elżbieta (ed.). 2001. Kognitywne podstawy języka i językoznawstwa. Kraków. Trzaska, Władysław (et al.). 1939. Encyklopedyczny słownik wyrazów obcych. Warszawa. 
Wesoły, Marian. 2019. Europa - droga wschodniorzymska (bizantyńska). In Stempin, Agnieszka (ed.). Geniusz Europy. Poznań, 21-30.

www.gazetaprawna.pl. www.mobile.natemat.pl. www.wiadomości.wp.pl.

Zaturski, Zbigniew (ed.). 1928. Słownik wyrazów obcych, zawierający około 14000 wyrazów obcych, zwrotów i przysłowi, używanych w języku potocznym, literackim, handlowym i korespondencji. Lwów.

Ziemkiewicz, Rafał. 2019. Odlot marszałka. In Do Rzeczy 33/3335, 12-18 sierpnia 2019, 7.

Zozulak, Ján. 2018. Interaction of Philosophy and Natural Sciences in Byzantine Empire. In Communications 20/1A , 8-15.

\begin{abstract}
SUMMARY: THE LINGUISTIC PICTURE OF BYZANTIUM IN THE OLD AND CONTEMPORARY POLISH LANGUAGE. Byzantium - recorded in the history of civilization and communication development as Roman Empire (Eastern Roman Empire; Byzantine Empire), evolving and developing from the 4th century and formally existing until the mid15th century, played an important role in the creation of the whole of modern Europe. It appears that Byzantium's contribution to the development of civilization and cultural heritage of Western Europe is undeniably substantial and has been evidenced and documented also by Polish researchers. The question, therefore, arises, as to the linguistic picture of Byzantium in the Polish language, both modern and contemporary as well as old. The analysis of sample research carried out among students yielded results that may be a cause for reflection, not only on the knowledge of the participants. The linguistic picture of Byzantium in contemporary and modern Polish language has two main versions: on the one hand, it is based solely on one's education, gained either in the process of schooling or individually, as sample results indicate. On the other hand, however, there is publicly expressed a dismissive view of Byzatium, linguistically marked as pejorative. With high probability, the first one is much more common (which the surveyed participants confirm) but transient due to the time-constrained exposure to information about the Empire, i.e. only during the school years. The other one is much more expansive, which is facilitated by mass media and the promotion of negation, alienation, contestation and hypercriticism in public discourse.
\end{abstract}

Prof. Elżbieta Skorupska-Raczyńska, PhD.

The Jacob of Paradies Academy

Departament of Humanities

Teatralna 25

66-400 Gorzów Wielkopolski

Poland

rektor@ajp.edu.pl

Joanna Rutkowska, PhD.

The Jacob of Paradies Academy

Departament of Humanities

Teatralna 25

66-400 Gorzów Wielkopolski

Poland

joarutajp@wp.pl 